\title{
Edukasi Gizi Seimbang dan Makanan Sehat untuk Imunitas Tubuh dalam Kondisi Pandemi Covid-19 di SMPN 2 Bayang, Kabupaten Pesisir Selatan
}

\author{
Putri Aulia Arza, Yeffi Masnarivan, Dhiya Fahdila Rahmah, Afifah Khairani Ananda \\ Fakultas Kesehatan Masyarakat, Universitas Andalas, Kampus Limau Manis, Padang, 25163. Indonesia \\ E-mail: putriauliaarza@ph.unand.ac.id
}

Keywords:

balance nutrition, immunity,

nutrition

education, student

Kata Kunci:

edukasi gizi, gizi seimbang, imunitas tubuh, siswa SMP

\begin{abstract}
Consumption of foods that can increase body immunity and are nutritionally balanced for school children especially in the current conditions amid the Covid-19 pandemic. SMPN 2 Bayang is one of the junior secondary schools located in Bayang District, Pesisir Selatan Regency. Healthy eating habits are the most important behaviors that can affect the state of nutrition and health of a person so that it is hoped that through education on balanced nutrition and healthy food for body immunity. The purpose of this community service is to increase junior high school students' knowledge about nutritionally balanced food and increase body immunity. The service began with an introduction to the approach to students and was continued with a pre-test. The next activity is nutrition education in the form of providing materials and simulations in preparing a balanced nutrition menu using video media, post-tests, and question and answer with prizes with community service participants. Participants and school principals were very enthusiastic in participating in the activity, because it was considered very important in the Covid-19 pandemic. From the pre-test and post-test results, it was concluded that there was a significant difference between the level of knowledge before and after nutrition education.
\end{abstract}

\section{ABSTRAK}

Konsumsi makanan yang dapat meningkatkan imunitas tubuh dan bergizi seimbang untuk anak sekolah penting untuk diperhatikan karena sangat berdampak terhadap kesehatan anak terutama pada kondisi saat ini ditengah pandemi Covid-19. SMPN 2 Bayang merupakan salah satu SLTP yang berada di Kecamatan Bayang, Kabupaten Pesisir Selatan. Pengamatan terhadap status gizi anak SLTP di SMPN 2 Bayang ini ada beberapa anak yang gemuk dan ada juga yang sangat kurus dan kecil. Kebiasaan makan yang sehat merupakan perilaku penting yang dapat mempengaruhi keadaan gizi dan kesehatan seseorang sehingga diharapkan melalui edukasi gizi seimbang dan makanan sehat untuk imunitas tubuh. Tujuan dari pengabdian masyarakat ini yaitu untuk meningkatkan pengetahuan siswa SLTP tentang makanan yang bergizi seimbang dan meningkatkan imunitas tubuh. Pengabdian diawali dengan perkenalan untuk pendekatan kepada siswa dan dilanjutkan dengan pre test. Kegiatan selanjutnya adalah edukasi gizi berupa pemberian materi dan simulasi dalam menyusun menu gizi seimbang dengan menggunakan media video, post test, dan tanya jawab berhadiah dengan peserta pengabdian masyarakat. Peserta dan kepala sekolah sangat antusias dalam mengikuti kegiatan, karena dirasa sangat penting dalam kondisi pandemi Covid-19. Dari hasil pre test dan post test disimpulkan adanya perbedaan yang signifikan antara tingkat pengetahuan sebelum dan setelah edukasi gizi. 


\section{PENDAHULUAN}

Pembentukan kualitas sumberdaya manusia sejak masa sekolah akan mempengaruhi kualitasnya pada saat mereka mencapai usia produktif. Oleh sebab itu, konsumsi makanan dengan gizi seimbang dan konsumsi makanan yang aman untuk anak sekolah penting untuk diperhatikan (Ditjen Bina Kesehatan Direktorat Gizi Masyarakat, 2001 dalam Taufiqurrahman, 2003). SMPN 2 Bayang merupakan salah satu sekolah tingkat SLTP yang berada di Kecamatan Bayang, Kabupaten Pesisir Selatan. Berdasarkan hasil pengamatan langsung bahwa lokasi sekolah ini cukup jauh dari kota. Pengamatan terhadap status gizi anak sekolah di SMPN 2 Bayang ini bahwa ada beberapa anak yang gemuk dan ada juga yang sangat kurus dan pendek.

Angka kasus infeksi virus Covid-19 di daerah ini berdasarkan data pantauan Covid-19 di Kabupaten Pesisir Selatan tertanggal 30 April 2020 jumlah pasien positif yaitu sebanyak 16 orang. Berdasarkan informasi dari masyarakat, masih ada pedagang makanan yang berjualan dengan menggunakan motor keliling. Peningkatan pengetahuan anak sekolah supaya mengkonsumsi makanan yang dapat meningkatkan imunitas tubuh dan bergizi seimbang sangat penting. Gizi lebih mempengaruhi kesehatan fisik dan mental, kualitas hidup terkait dengan kesehatan, serta menghabiskan uang (Dixon, 2010). Sementara itu, kekurangan gizi mampu meningkatkan risiko penyakit infeksi, memperlambat pertumbuhan dan perkembangan serta menurunkan tingkat kecerdasan. Secara bersama-sama, baik gizi kurang maupun gizi lebih mampu menganggu proses pertumbuhan dan perkembangan anak, meningkatkan risiko penyakit serta meningkatkan pengeluaran untuk biaya rumah sakit. Kebiasaan makan yang sehat merupakan perilaku paling penting yang dapat mempengaruhi keadaan gizi dan kesehatan seseorang sehingga diharapkan melalui edukasi gizi terhadap makanan jajanan sehat dan gizi seimbang ini, anak sekolah dasar memahami bagaimana memilih makanan jajanan yang sehat dan pola makan yang sehat. Berdasarkan beberapa penelitian menunjukkan bahwa edukasi gizi merupakan salah satu metode yang dapat meningkatkan pengetahuan siswa (Agnesia 2020; Arza dkk, 2019; Sekti, 2019). Anak sekolah SLTP dapat memahami bagaimana memilih makanan yang dapat meningkatkan imunitas tubuh dan bergizi seimbang.

Akhir-akhir ini informasi mengenai gizi seimbang siswa SMP yang sedang dalam masa pertumbuhan serta makanan sehat yang bagus untuk imunitas tubuh dapat diperoleh dengan mudah melalui informasi media online maupun iklan di televisi, akan tetapi masih kurang efektif meningkatkan pengetahuan siswa SMP. Adapun tujuan dari pengabdian masyarakat ini yaitu untuk meningkatkan pengetahuan gizi siswa SMP tentang gizi seimbang dan makanan sehat yang dapat meningkatkan imunitas tubuh ditengah pandemi Covid-19.

\section{METODE}

Kegiatan pengabdian masyarakat dilaksanakan di SMPN 2 Bayang, Kecamatan Bayang, Kabupaten Pesisir Selatan. Peserta pengabdian masyarakat terdiri dari siswa kelas 7 dan 8 sebanyak 30 orang. Kegiatan yang dilakukan adalah pre-test, pemberian materi mengenai gizi seimbang, tumpeng gizi seimbang dan makanan sehat yang dapat meningkatkan imunitas tubuh dan diakhiri dengan post-test. Diakhir sesi juga dilakukan tanya jawab berhadiah bahwa bagi peserta yang menjawab pertanyaan dengan benar, selain itu peserta yang bisa menyusun menu gizi seimbang dengan menggambarkan secara detail dan jenis-jenis makanan yang dapat meningkatkan imunitas tubuh. Untuk melihat peningkatan dan perbedaan rerata tingkat pengetahuan siswa pada awal dan akhir kegiatan ini dianalisis menggunakan Paired sample ttest. 
Untuk meningkatkan derajat kesehatan dan imunitas tubuh anak SMP karena mengkonsumsi makanan yang tidak bergizi seimbang ditambah lagi dengan kondisi pandemi Covid-19 ini dan untuk mencegah masalah gizi pada anak SMP maka dilakukan rencana kegiatan yang dituliskan pada Tabel 1.

Tabel 1. Rencana Kegiatan

\begin{tabular}{lll}
\hline No. & Kegiatan & Langkah-Langkah Solusi \\
\hline 1. & Edukasi tentang gizi & Memberikan edukasi gizi kepada anak SLTP \\
& seimbang & $\begin{array}{l}\text { menggunakan leaflet yang akan dibagikan dengan } \\
\text { metode daring yaitu melalui whatsapp tentang gizi } \\
\text { seimbang melalui media bergambar yaitu "Tumpeng Gizi } \\
\text { Seimbang" dan "10 Pesan Gizi Seimbang". }\end{array}$ \\
\hline 2. & $\begin{array}{l}\text { Edukasi gizi tentang memilih } \\
\text { makanan yang dapat } \\
\text { meningkatkan imunitas } \\
\text { tubuh }\end{array}$ & $\begin{array}{l}\text { Edukasi gizi dengan mengirim video animasi tentang } \\
\text { makanan yang dapat meningkatkan imunitas tubuh dan }\end{array}$ \\
& $\begin{array}{l}\text { mengadakan kuis online dengan meminta anak SLTP } \\
\text { memilih makanan-makanan yang yang baik untuk daya } \\
\text { tahan tubuh. }\end{array}$ \\
\hline
\end{tabular}

\section{HASIL DAN PEMBAHASAN}

1. Pelaksanaan Kegiatan Pengabdian Masyarakat

Kegiatan pengabdian masyarakat dilaksanakan pada hari Sabtu, 11 Juli 2020. Kegiatan pengabdian masyarakat dilaksanakan di SMPN 2 yang berada di Kecamatan Bayang, Kabupaten Pesisir Selatan. Pelaksanaan pengabdian dilaksanakan dengan menerapkan protokol kesehatan karena dalam kondisi pandemi Covid-19. Sebelum memasuki ruangan semua peserta diminta untuk mencuci tangan dengan menggunakan sabun dan air mengalir yang sudah disediakan, kemudian peserta duduk di kelas dengan jarak kurang lebih 1 (satu) meter. Peserta pengabdian masyarakat terdiri dari siswa kelas 7 dan 8. Peserta dikumpulkan di satu kelas pada jam yang telah ditentukan oleh pihak sekolah. Jumlah peserta pengabdian masyarakat menjadi 33 orang disebabkan pihak sekolah sangat tertarik dengan kegiatan edukasi gizi dan minat dari siswa. Kegiatan ini disambut baik oleh kepala sekolah SMPN 2 Bayang, ibu Linda Astuti, S.Pd yang dalam sambutan pembukanya mengatakan bahwa kegiatan ini sangat penting dan waktunya juga tepat karena proses belajar mengajar di sekolah akan dimulai pada tanggal 13 Juli 2020. Sebagaimana telah diketahui, sekolah-sekolah di Kabupaten Pesisir Selatan sudah kembali melaksanakan proses belajar mengajar secara tatap muka. Oleh karena itu, disamping menerapkan protokol kesehatan, juga dipandang perlu untuk mengharapkan para siswa untuk dapat meningkatkan daya tahan tubuhnya dalam rangka mencegah terinfeksi virus Covid-19 yang masih menjadi suatu ancaman di Sumatera Barat termasuk di Kabupaten Pesisir Selatan. Salah satu guru pendamping pada kegiatan ini juga menyampaikan apresiasinya untuk kegiatan ini karena selain menambah ilmu siswa, juga bermanfaat bagi guru-guru untuk menambah ilmu terkait peranan gizi dalam meningkatkan imunitas tubuh

Kegiatan diawali dengan perkenalan tim pengabdian termasuk perkenalan dari pihak media massa yang akan meliput kegiatan ini. Tim juga menjelaskan maksud dari kegiatan pengabdian masyarakat kepada peserta. Setelah perkenalan, dilakukan pre test menggunakan google form yang dibagikan langsung melalui whatsapp peserta untuk menghindari terlalu banyak kontak fisik karena masih dalam kondisi pandemi Covid-19. Pre test ini bertujuan untuk mengetahui pengetahuan awal peserta mengenai gizi seimbang dan makanan yang baik untuk imunitas 
tubuh. Setelah siswa selesai mengisi google form yang sudah disediakan, peserta diberikan materi tentang gizi seimbang dan peserta diberikan leaflet. Banner pedoman gizi seimbang (PGS) yang terdiri dari 10 pesan dan tumpeng gizi (Gambar 1) juga disediakan di depan kelas. Banner PGS dan tumpeng gizi ini diserahkan ke sekolah dengan harapan siswa lain yang tidak mengikuti kegiatan ini juga bisa membaca tentang 10 pesan gizi seimbang yang dikeluarkan oleh kementerian kesehatan dan juga tentang tumpeng gizi yang berisi gambaran porsi menu makanan sehat dalam sehari. Selain itu, Materi tentang makanan bergizi yang bagus untuk meningkatkan imunitas tubuh juga disampaikan pada kegiatan pengabdian ini, makanan yang disampaikan pada materi ini yaitu buah-buahan yang sangat mudah untuk didapatkan dan harga yang terjangkau sehingga ilmu yang diperoleh langsung diterapkan siswa dan disampaikan kepada orang tua.

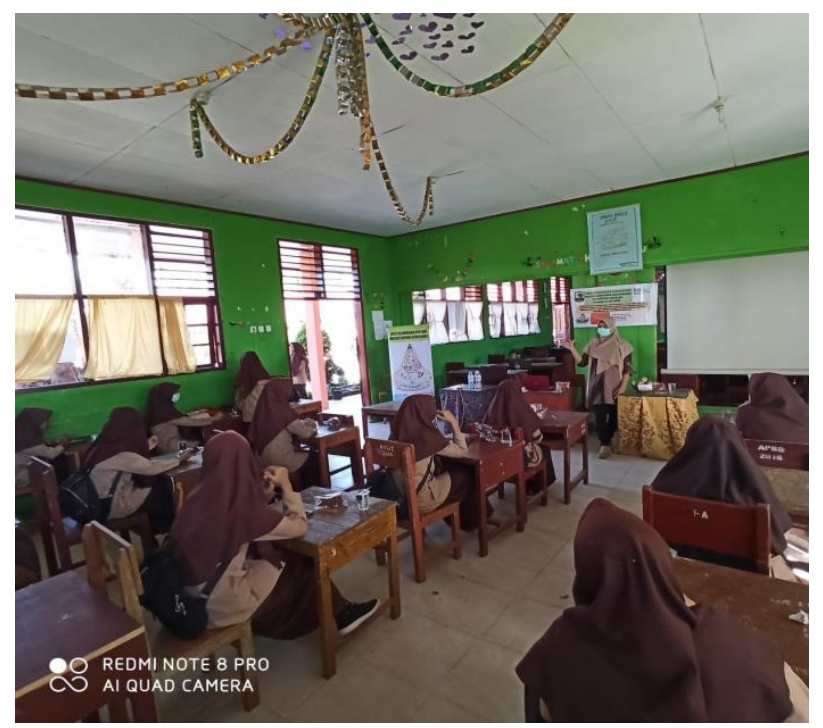

Gambar 1. Pemaparan materi dan penjelasan Banner Gizi Seimbang

Setelah diberikan materi gizi seimbang, dilakukan diskusi yang juga diikuti oleh kepala sekolah sehingga peserta juga antusias untuk berdiskusi tentang makanan yang dapat meningkatkan imunitas tubuh terutama buah dan sayur dan siswa juga semangat untuk berbagi pengalaman tentang kebiasaan konsumsi buah dan sayur (Gambar 2). Berdasarkan hasil wawancara dengan siswa, umumnya siswa jarang mengkonsumsi sayur dibandingkan buah. Buah yang biasa dikonsumsi yaitu jeruk dan pisang karena harganya murah dan selalu tersedia. Setelah sesi diskusi dan tanya jawab, siswa diberikan beberapa pertanyaan berhadiah, peserta yang bisa menjawab pertanyaan dengan tepat diberikan doorprize untuk memotivasi siswa supaya semangat dalam menjawab pertanyaan (Gambar 3). Pada tahap akhir dari kegiatan pengabdian ini, semua siswa dan guru diberikan paket buah-buahan yang merupakan bagian inti dari kegiatan pengabdian masyarakat ini, dengan tujuan meningkatkan kesadaran siswa akan pentingnya konsumsi buah ditengah pandemi Covid-19 ini untuk meningkatkan daya tahan tubuh (Gambar 4). 


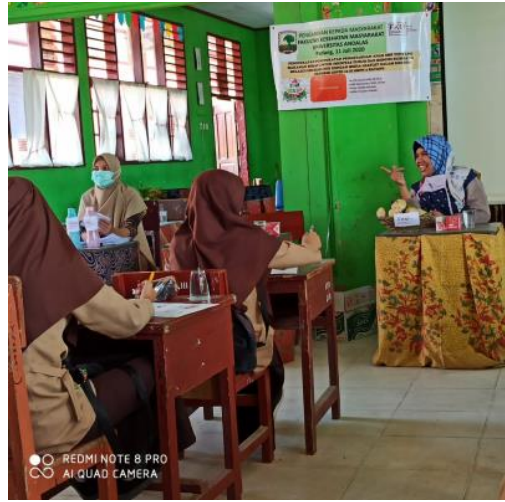

Gambar 2. Diskusi bersama Kepala Sekolah

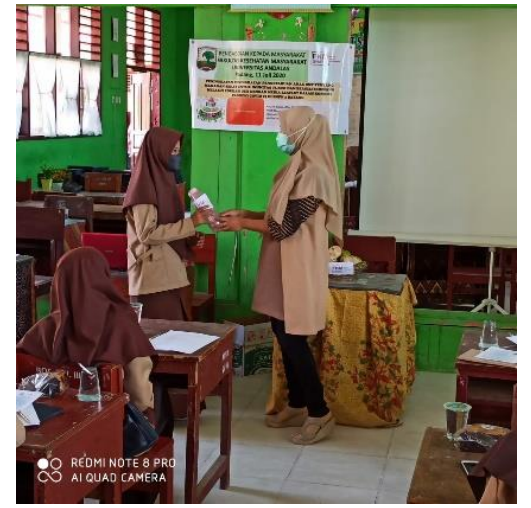

Gambar 3. Penyerahan Doorprize

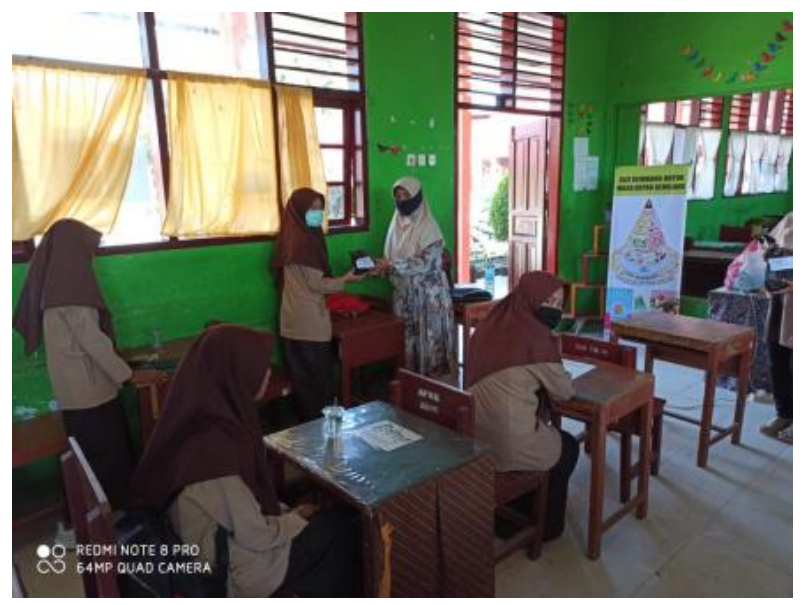

Gambar 4. Penyerahan Paket Buah-Buahan

2. Hasil Pre Test dan Post Test Peserta Kegiatan

Perbedaan tingkat pengetahuan sebelum dan setelah dilakukan edukasi gizi tentang gizi seimbang dapat dilihat pada tabel di bawah ini:

Tabel 2. Hasil Uji Perbedaan Tingkat Pengetahuan Sebelum dan Sesudah Edukasi Gizi Seimbang

\begin{tabular}{cccc}
\hline Variabel & Mean & P Value & $\mathrm{n}$ \\
\hline Pre Test & 5,2 & 0,0001 & 30 \\
Postest & 7,7 & & \\
\hline
\end{tabular}

Berdasarkan Tabel 2 terlihat bahwa skor rata-rata tingkat pengetahuan pada pre test adalah 5,2. Pada post test didapat rata-rata tingkat pengetahuan adalah 7,7 . Hasil uji statistik didapatkan nilai $P$ value 0,0001 . Berdasarkan hasil tersebut dapat disimpulkan ada perbedaan yang signifikan antara tingkat pengetahuan sebelum (pre test) dan setelah (post test) edukasi gizi. Hal ini sejalan dengan beberapa hasil kegiatan pengabdian yang menyatakan bahwa edukasi gizi bermanfaat meningkatkan pengetahuan siswa (Agnesia, 2020; Arza, 2019; Sekti, 2019). 


\section{KESIMPULAN DAN SARAN}

Kegiatan pengabdian masyarakat disambut baik oleh kepala sekolah dan berjalan dengan baik. Terlihat dari respon positif kepala sekolah dan guru-guru dan antusias dari siswa-siswa SMP tersebut dalam mengikuti kegiatan pengabdian masyarakat ini dan langsung mengkonsumsi buah-buahan yang dibagikan. Ada perbedaan yang signifikan antara tingkat pengetahuan sebelum (pre test) dan setelah (post test) edukasi gizi.

\section{UCAPAN TERIMA KASIH}

Terima kasih dihaturkan kepada Fakultas Kesehatan Masyarakat, Universitas Andalas yang telah mendanai kegiatan ini melalui Hibah DIPA FKM Tahun 2020, sehingga dapat terlaksananya kegiatan ini dengan mitra SMPN 2 Bayang, Kabupaten Pesisir Selatan. Terima kasih juga disampaikan kepada mitra yang telah bekerjasama dengan baik sehingga tercapainya tujuan yang diharapkan.

\section{DAFTAR PUSTAKA}

Agnesia, D. (2020). Peran Pendidikan Gizi dalam Meningkatkan Pengetahuan, Sikap dan Perilaku Gizi Seimbang pada Remaja di SMA YASMU Kecamatan Manyar Kabupaten Gresik. ACADEMICS IN ACTION Journal of Community Empowerment, 1(2), 64-76.

Arza, P. A., Masnarivan, Y., Dewi, R. K., Fitriyani, F., Rahmah, D. F., \& Ananda, A. K. (2020). Edukasi Gizi Seimbang dan Makanan Jajanan Sehat di SDN 39 Pasar Ambacang Kota Padang. BULETIN ILMIAH NAGARI MEMBANGUN, 3(1), 30-37.

Dixon, J. B. (2010). The effect of obesity on health outcomes. Molecular and cellular endocrinology, 316(2), 104-108.

Pesisir Selatan. 2020. Data Pantauan Covid-19 Kab. Pesisir Selatan. https://covid19.pesisirselatankab.go.id/

Sekti, R. M., \& Fayasari, A. (2019). Edukasi gizi dengan media audiovisual terhadap pola konsumsi sayur buah pada remaja SMP di Jakarta Timur. Jurnal Ilmiah Kesehatan, 1(2), 7788.

Taufiqurrahman. 2003. Hubungan Kebiasaan Sarapan dengan Status Gizi di SD Perkotaan. Skripsi. Surabaya: Universitas Airlangga. 